\title{
I kædedansens fodspor - efter Luther og Palladius
}

\author{
af arkivar og projektforsker Lene Halskov Hansen, \\ Dansk Folkemindesamling ved Det Kgl. Bibliotek
}

$2017 \begin{aligned} & \text { er året hvor Danmarks salg } \\ & \text { af de Vestindiske øer for }\end{aligned}$ hundrede år siden markeres, debatteres og diskuteres, som f.eks. i udstillingen "Blinde vinkler" på Det Kgl. Bibliotek. Samtidig fejrer adskillige lande Martin Luthers startskud på reformationen for 500 år siden, hvor han slog sine 95 teser op på porten til slotskirken i Wittenberg. Også herom har Det Kgl. Bibliotek en udstilling med titlen: "Jeg bliver din død, pave! Luthers reformation og splittelsen af Europa”, som åbner november 2017.

Mit tema knytter sig til Luther. Ikke direkte, men gennem den sjællandske biskop og professor i teologi Peder Palladius (1503-1560) som var med til at omsætte reformtanker til virkelighed på Sjælland. Det fik blandt andet indflydelse på en folkelig dansetradition.

\section{Palladius og dans i kirken}

Syv-otte år efter den lutherske kristendom i 1536 officielt blev indført i Danmark, skrev Peder Palladius en visitatsbog om hvad der nu passede sig, og især ikke passede sig, i den nye protestantiske kirke. Han rejste rundt til alle 390 kirker i sit stift og belærte menighederne med formaninger og advarsler. Det var ikke kun katolske skikke og ritualer han ville udrydde, og protestantiske han ville indføre. Det var også folkelige traditioner udfoldet i og uden for kirken som han ville have orden på eller bugt med, som f.eks. det at danse inde i kirken mandag eller tirsdag $\mathrm{i}$ bryllupsugen: Al den
"slemmen oc demmen [sviren og sværmen] oc dantzen, met pijbe oc tromme, som skeede her vdi Seland, inden kircke dørrene, om mandag heller tijsdag i bryllupsugen, det hørde dieffuelen [djævelen] aff helffuede til, oc er derfor afflagt til landsting, ved kongens suerd $[\ldots]^{1}$

Det var alvor, og vi må formode at dansen ganske hurtigt ophørte i kirkerne. Palladius havde selvsagt ikke til formål at beskrive den dans han ville forbyde, men med kædedans som middelalderens mest udbredte dans blandt både høj og lav, er dette et kvalificeret bud. De fleste kirker havde i senmiddelalderen stadig ikke bænke eller stole til menigheden, kun en bænkerække langs væggene til de syge og de gamle. Kirkerummet var derfor særdeles velegnet til dans. De der står op, tager blot hinanden i hænderne, og som kædedansere fylder de ikke meget mere i rummet end når de står stille. I en kædedans holder man hinanden i hænderne, lillefingrene, om skuldrene eller har et tørklæde eller en krans imellem sig, afhængigt af hvilket land, område eller dans der er tale om. Man danser sidelæns, fremad eller skråt fremad med fælles dansetrin i en lukket eller åben kæde, mod højre eller mod venstre. 

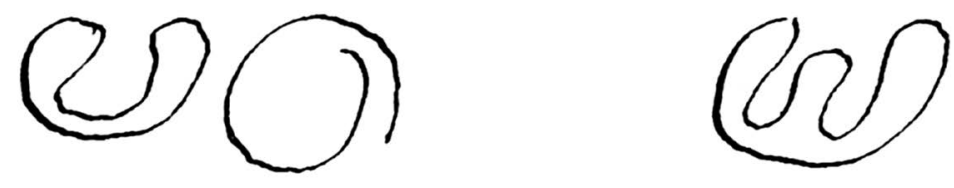

Kededansformationer, hhv. lukket, åben og lukket.

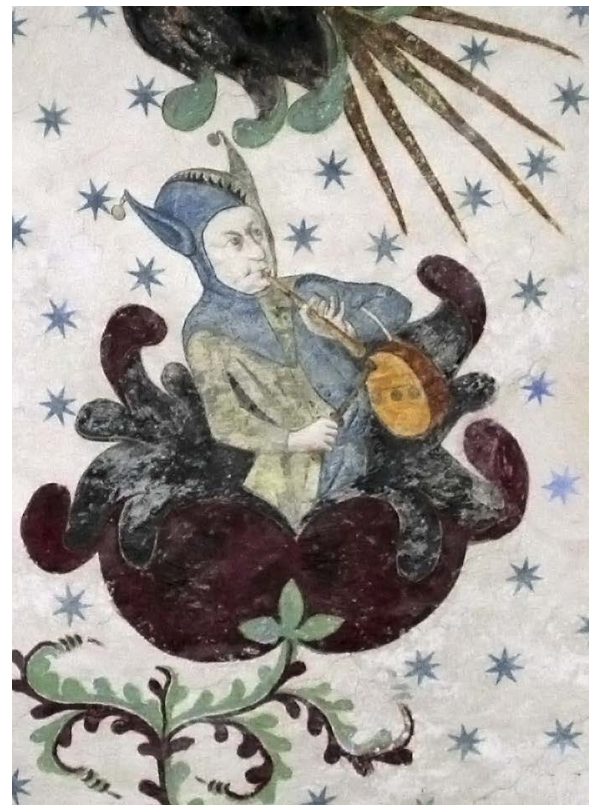

Musiker i narrekostume, Helligtrekongers Kapel, Roskilde. Foto ved forf.
Udover at pibe både kan betyde sækkepibe og fløjte, er pibe og tromme også et samlet begreb for en enhåndsfløjte og enhåndstromme spillet samtidigt af én person. En sådan musiker i narrekostume finder vi i en blomsterkapsel i hvælvingen i Helligtrekongers Kapel i Roskilde domkirke, malet i 1464. Traditionen at spille på enhåndsfløjte og -tromme eksisterer stadig i Baskerlandet i Sydfrankrig og Nordspanien, ligesom englænderne spiller pipe and tabor til deres særegne form for rækkedans eller processionsdans, morris dance. I Danmark er Poul Høxbro i dag den ypperste pibe og tromme-musiker.

\section{"Harboskrep udi en lang Rad"}

Om kædedansen i Danmark fortsatte uden for kirken efter Palladius' kraftfulde advarsel, ved vi ikke med sikkerhed. Poul Colding Jensen refererer imidlertid i 1922 i sin latinske ordbog, Etymologicum Latinum til en dans kaldet harboskrep: "Ducere restem vel funem, est choreas agentium longa serie," oversat af samme til: "som at danse Harboskrep och udi en lang Rad haffue haandklæde imellom sig." 2 Beskrivelsen, at der danses i en lang "rad," tyder på en åben kædedans.

Den danske sprogforsker Peder Syv (1631-1702) har harboskrep med i sin Almindelige danske Ordsproges anden Deel, 
1688: "dandse (lege) harboskrep, er en hofferdig dands i Jylland," en stolt dans.

\section{Herberg-skrep, Sudderdands eller Toespring}

Gehejmeråd Matthias Moth (16491717) iværksatte i 1686 den første officielle landsindsamling af ord til et leksikon. I den forbindelse fandt han det nødvendigt også at skaffe sig kendskab til folkemålets gloser, dvs. "besynderlige ord," som skibsfolk, bønder, håndværkere m.fl. benyttede sig af samt gloser om brugsgenstande og skikke. Han henvendte sig til landets biskopper for gennem dem at få opgaven fordelt mellem sproginteresserede præster og latinskolelærere. ${ }^{4}$ Moths udkast til et dansk leksikon og glosebogen med dialektord findes i Håndskriftsamlingen på Det Kgl. Bibliotek. ${ }^{5}$ Dog først i 2013 blev ordbogen udgivet takket været Dansk Selskab for Sprog og Litteratur, desværre uden dialektordene, folkemåls-gloserne. ${ }^{6}$

Et af de "besynderlige" ord indsendt fra Ribe Amt til Moth i 1697, var Harbo-skrep eller Herberg-skrep. Moth forklarer Harbo som den der er født i Harsyssel; et lidt mindre område end det tidligere Ringkøbing Amt. Skrep eller skrep betyder "prygle, ilde medfart" og betegner ogsà "en juleleg blandt Bønder og gemen Mand, hvor de dunke hinanden i Ryggen eller støde hverandre i Rumpen med et knæ." Sammensætningen af de to ord til Herbergskrep - eller Harboskrep, Herreboskrep, Harpeskrep, Herbergskræp - betegner imidlertid en "runde-dans" der også kaldes "Toespring," hvortil der synges gammenskvad, dvs. skæmteviser, humoristiske viser. Moth noterer at den danses mange steder her i Landet, især i Sønder og Nørre Bork syd for Skjern. ${ }^{7}$ Med "Landet" menes formentlig Harsyssel eller muligvis Jylland. Runde-dans kan tolkes som en lukket kædedans:

"Herberg-skrep er den Runde-dans, som ellers kaldes Sudderdands heller Toespring, sjunes at komme [af] at skræppe i Herberget; er en meget brugelig Dans mange Steder her i Landet, i Synderlighed i Nør-herred i Sønder- og Nørre-Borch Sogner, hvor af den og kaldes Børchind-dands, fordi Borch-Folk, kaldede Børchinderne, excellerer i at træde denne Dans. Hinc proverb.: Børchinderne kan baade træde en Dans og løfte en Kvaj'; thi denne Dans trædes efter adskillige Gammenskvaj' med sine Bikvaj og Omkvaj. Kvad = Vise, inde: Gammens-kvad, Bi-kvad, Om-kvad, Gjenkvad."

At skæmteviserne har "bikvaj," dvs. omkvæd mellem verslinjer, og "omkvaj" efter versene tyder på at der kan være tale om skæmteballader, der, ligesom de mere alvorlige gamle, fortællende folkeviser (ballader), har rødder tilbage til middelalderen, omend den enkelte version kan være af nyere herkomst.

Omkring 150 år senere ved vi at der bl.a. i samme område blev danset en kædedans kaldet tospring.

\section{Tospring}

"De så da hele brudefølget komme springende og syngende ind gennem porten, holdende hinanden $i$ hænderne i en åben kæde. Musikanterne var i spidsen for kæden. Den dansende kæde drog gårdspladsen rundt og forsvandt så, samme vej som den var kommen. Tante sagde, at det de 


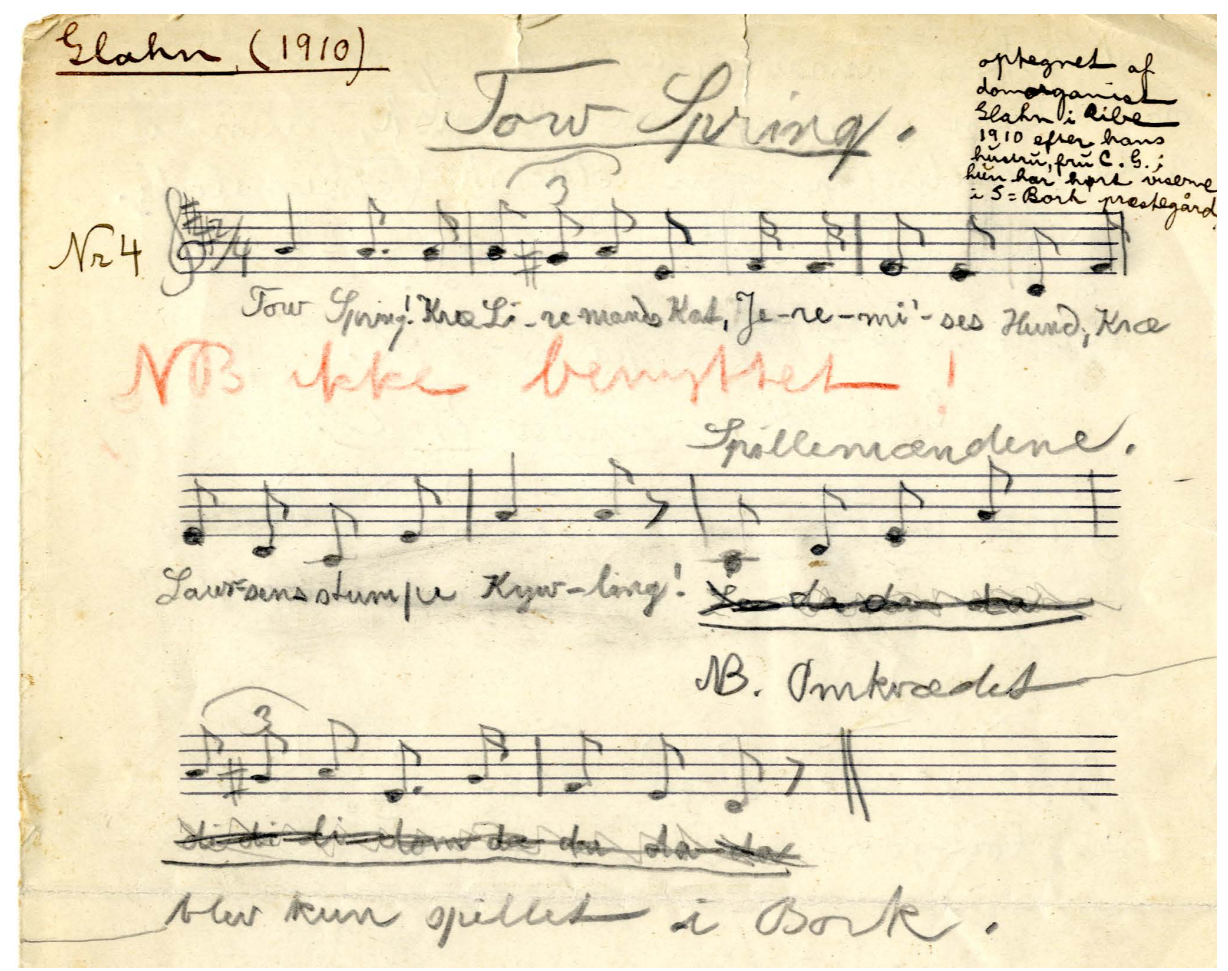

Tospring: Optegnelse af domorganist Glahn fra 1910 (Dansk Folkemindesamling, 1906/12).

dansede var tospring." Sønder Bork syd for Skjern, o. 1853.

I begyndelsen af 1900-tallet var den nystiftede Foreningen til Folkedansens Fremme og Dansk Folkemindesamling begyndt at optegne folkelige danse. Herfra har vi en række kilder som beskriver trinnene til og beretter om en kædedans, ofte kaldet tospring, der blev danset $\mathrm{i}$ sidste del af 1800-tallet på den jyske vestkyst, primært op langs Ringkøbing fjord, bl.a. i Sønder Bork. Den blev især danset på brylluppets andendag; bryllupperne varede nu kun tre dage og ikke en hel uge som i Palladius' tid. Bryllupsgæsterne samlede sig $i$ en lang åben kæde med mu- sikerne i spidsen og dansede da afsted hen over markerne til en eller flere nabogårde. Der berettes tilmed at de nogle steder også dansede ind stuehuset og rundt $i$ alle stuerne. Der blev gerne serveret brændevin og småkager under dansen eller som en pause i dansen. Kæden fortsatte da videre til næste gård eller direkte tilbage til bryllupsgården. Det kunne tage et par timer i alt. Når danserne nåede tilbage til bryllupsgården, var bordene på ny dxkket op. Ud over danseglæde og det sociale aspekt $i$ at danse sammen havde tospring den praktiske funktion at give tid og plads til at rydde af bordene og stille an til endnu et måltid. 
Grundtrinnene til dansen er nøjagtig som den færøske kvaddans, ${ }^{10}$ en af de bretonske kædedanse, en af serbernes kædedanse, en af kurdernes kædedanse m.fl. Nogle beskriver i al enkelthed dansen som to skridt til venstre og et til højre - og modsat på de egne der dansede mod højre. Fra Ådum sogn forlyder det: "Man sprang først nogle spring til den ene side og så til den anden, men ikke lige meget til begge sider, således at kæden efterhånden flyttede sig rundt.." ${ }^{11}$ Det har grundlæggende været en livlig og springende dans. Men ikke altid. Palle Fløe skrev i 1870-1871 at "af de Ældre udføres Dandsen meget alvorligt og ikke uden Ynde." ${ }^{12}$ Forskellighederne i optegnelserne afspejler både dansevariationer og manglende metoder til at beskrive dansetrin og -bevægelser.

Flere steder indgik der et afsnit i dansen hvor man skiftevis hoppede to gange på det ene ben og to gange på det andet, mens man sparkede ud med det 'frie' ben og svingede heftigt frem og tilbage med armene. Nogle optegnelser viser også at danserne sang et dansevers eller vrøvlevers til musikken, f.eks.: " To Spring Kre Liermanns kat, Kre Lavsens Kat har Killing, Hej sa farval og Tak, vi kommer igen i Morgen.. ${ }^{13}$ Det er uvist om danserne spontant satte i med verset, eller om det blev styret af f.eks. fordanseren eller spillemanden.

Enkelte optegnelser bevidner at tospring også har været danset $i$ andre sammenhænge end til bryllupper: Til julegilder i 1700- og 1800-tallet; ${ }^{14} \mathrm{i}$ det fri i begyndelsen af 1800-tallet, øjensynligt danset af ungdommen mens de sang "dans tospring tirre lirre mands kat, Jeremias' hund, Kræ Lausens toppe killing"; og af karlene og pigerne der i slutningen af 1800-tallet dansede tospring fra laden op til hoveddøren på Lundenæs gård når de var færdige med hoveriarbejdet. Dansen endte i en halvkreds om døren, og her blev beværtet med kage og mjød og folkene fik deres "drikkepenge."15

\section{Trendans på Mandø}

Den nyeste optegnelse vi har i Danmark af en kædedans der stadig var i brug, er fra den lille Vadehavsø Mandø ud for Ribe.

Arkivar Hakon Grüner-Nielsen og en ung student Johannes Egedal var på indsamlingstur i Jylland i 1916. På Fanø fortalte de gamle mænd dem at mandøboerne dansede en dans som de sang skæmteviser til, og hvor "det så ud, som om herrerne med knæet sparkede damerne i enden."16 At noget kunne tyde på kædedans, og endda danset til sang, var så usædvanligt at arkivaren og studenten fik travlt med at komme over til Mandø. Her gik især Johannes Egedal rundt fra dør til dør, blevet budt inden for til kaffe, og dansede rundt i køkkenet med husets beboere for at forstå hvilke danse der i det hele taget var i brug på øen. Grüner-Nielsen og Egedal organiserede dernæst en danseaften i forsamlingshuset, hvortil de inviterede øens spillemænd og omkring 20 af de gode unge og ældre dansere som Egedal havde besøgt. Først da ville dansene for alvor kunne studeres og beskrives.

Der blev danset i mere end ét køkken, skrev Egedal i sin dagbog der som sidegevinst også giver os et indblik i hvad indsamling af dans kunne indebære. Selv at danse og at organisere en 
dansekomsammen var og kan være en nødvendig del af optegnelses- og analysemetoden.

Da aftenen oprandt, blev der hurtigt fuldt hus idet der også kom en del nysgerrige der ikke var indbudte. Aftenen blev indledt med kædedansen som øboerne kaldte trendans; de unge kaldte den tripdans, uvist hvorfor. Den blev danset i en stor kreds hvor alle har front skråt mod venstre; nogle gik ind i kæden parvis, men det var ikke afgørende. Hver danser holdt sin højre hånd bag på sin lænd og havde med venstre fat $\mathrm{i}$ højre hånd på den der dansede skråt foran. Dansen udførtes med fem trin, første fire gangtrin mod venstre med noget bøjede knæ, derefter et hop ind mod kredsens midte, idet man satte af med og kom ned på højre fod; venstre fod støttede da på gulvet. Under springet blev hoften skudt godt ud til højre. Hvor dansetrinnet i tospring går over seks slag, går det således over fem $\mathrm{i}$ trendansen.

Det var som sagt bemærkelsesværdigt at kunne optegne en kædedans i Danmark i 1916 hvor den endnu indgik i et danseforløb ved særlige lejligheder. Og mindst ligeså bemærkelsesværdigt at der blev sunget til kædedansen uden musik. ${ }^{17}$ De to skæmteviser findes sidst i artiklen; den ene er en version af "Møllerdatteren," kendt fra Højskolesangbogen som "Der stode tre skalke." Dansen kan gennem kilderne føres tilbage til første halvdel af 1800-tallet.

\section{Et overblik over de nævnte kilder} Med diverse usikkerheder om dansetype har vi været omkring sandsynligheden for at der blev danset kædedans i kirkerne til pibe og tromme i en uvis periode frem til Palladius' indgriben i
1543-44. Vi har hørt om en dans i 1622, harboskrep, som foregår i en lang række hvor danserne holder et mindre klæde imellem sig, og som antyder kædedans. Om en dans der i 1697 også kaldes harboskrep, herbergskrep, sudderdans eller toespring hvortil der synges skæmteballader; selve dansen beskrives ikke i denne kilde. Om en dans ved julegilder i 1700-1800-tallet som kaldes tospring uden at den beskrives nøjere. Om vist nok ungdommen der dansede tospring $\mathrm{i}$ det fri i begyndelsen af 1800-tallet; her antydes det indirekte at der er tale om en kædedans. Om dansen tospring der beskrives som en kædedans, og som blev danset i sidste del af 1800-tallet til bryllupper og af karle og piger til Lundnæs når de var færdige med hoveriarbejdet. Og endelig har vi kædedansen på Mandø - trendansen eller tripdansen - danset til to skæmteviser, optegnet i 1916 med referencer tilbage til første halvdel af 1800-tallet. Om der er kontinuitet mellem disse, eller nogle af disse beskrivelser og optegnelser, er muligt, men ikke beviseligt.

\section{En fortærsket dansefrise}

Med alle disse kilder vi nu har læst, er vi ikke blevet meget klogere på hvad det vil sige at danse kædedans. De skriftlige kilder afslører nok en smule om variationer i dansen, som at nogle dansede yndefuldt, andre sprang. Men vi står tilbage med spørgsmålene om dansernes eventuelle fælles og individuelle danseudtryk. På hvilke måder kan en danser få sin danseglæde tilfredsstillet inden for kædedansens stramme rammer? Der er ikke plads til fordybelse i denne artikel, men et par centrale aspekter af det at danse, skal antydes. 


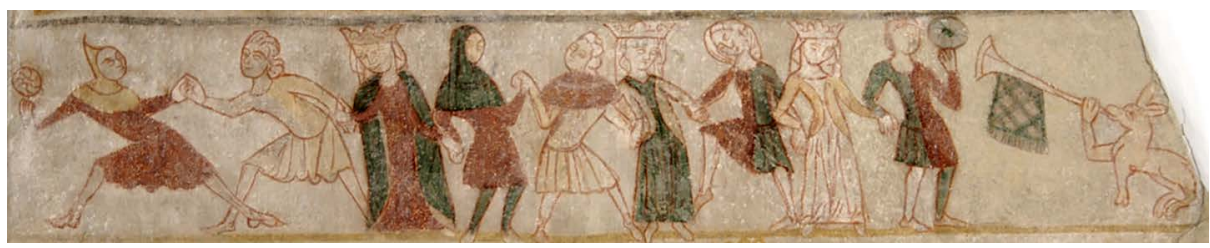

"Dansefrisen" fra Ørslev kirke ved Skalskør. Foto ved forf.

Flow og spændstighed

Dansefrisen i Ørslev kirke ved Skælskør trækkes ofte frem som et eksempel når talen falder på balladesang til kædedans i middelalderen - også selv om der ingen sang er i frisen.

Selve dansen har været tolket på forskellige måder gennem tiderne. Knud Kannik mente at kunne genkende de enkelte trin i færingernes kvaddans repræsenteret af hver danser, dog uden hensyn til tidsfølgen. I forlængelse heraf mente Iørn Piø at nok danser de kædedans, men "hver danser træder øjensynligt sit eget trin." 18

Med et fornyet danseblik skal vi i stedet betragte og læse dansefrisen som dans.

Danserne er udtryksfulde. Det er selvsagt ikke en naturalistisk gengivelse af virkeligheden, men realistisk i den forstand at det giver indtryk af en levende dans, sådan som den endnu kan opleves i forskellige egne af verden, hvor hvert land eller område, og hver person, har sine forskelligartede karakteristika.

I dansefrisen er der øjenkontakt mellem nogle af danserne, og selv om de formentlig danser de samme trin, så udfører de ikke nødvendigvis trinnene ens. Her burde analysen egentlig stoppe, for allerede her har maleren uden tvivl taget sig sine friheder i forhold til den faktiske virkelighed. Og dog, for tager vi et fotografi af en kædedans der er godt i gang, så kan man få et billede der viser at én danser hviler på højre ben, mens en anden hviler på venstre, at én danser sparker fremad med foden, en anden bagud, at nogle vender sig mod højre, andre mod venstre osv. Hvis det er gode dansere der formår at variere sin dans efter den sang eller musik de hører og samtidig i kroppen kan bevare den grundlæggende fælles rytme i dansen, så kan vi få et billede der i princippet ligner dansefrisen i Ørslev kirke. Måske knap så malerisk, men livligt og varieret. To forskellige underdelinger af et trin kan betyde at danserne i et split sekund f.eks. hviler på henholdsvis det højre og venstre ben. På Færøerne i dag kan vi se hvordan danserne vender og drejer sig mod hinanden styret af deres oplevelse af og engagement i visens handling og behovet for at dele det med sidemanden. ${ }^{19}$ I modsætning hertil har jeg set kurdere danse med meget små og hurtige underdelinger i dansen, og at de veksler mellem et 'behersket' udtryk og et udtryk med større bevægelser samtidig med de hurtige underdelinger.

Danseforskere taler om at det vigtigste element i dans er bevægelsens "flow," at dansen er som en sammenhængende strøm af bevægelse. Flowet er grundlaget for at bevægelserne og trinnene bliver til dans, og at danseren kan variere uden at falde ud af og ødelægge den grundlæggende strøm af bevægelse. ${ }^{20}$ Min erfaring 
med og studier af ikke mindst kædedans med færinger, bretoner, grækere og kurdere viser at kroppens spændstighed og parathed - modsat anspændthed og afslappethed - også er afgørende for at man kan danse i længere tid uden at kroppen bliver træt, udmattet. Danseren kan hvile i sin spændstighed og derved veksle mellem et roligt danseudtryk og et 'udfoldet' danseudtryk med flere eller mere markante bevægelser og variationer. Spændstighed og flow er to sider af samme sag. Hvis de ikke er til stede bliver tospring og trendans noget af det kedeligste at danse: man flytter kroppen to skridt til venstre og et til højre eller fire gåtrin skråt fremad og et hop mod midten - uden kropslighed. Det er der ingen dans $\mathrm{i}$.

\section{Afslutning}

Jeg har fremlagt et glimt af vores dansehistorie som ikke er almindelig kendt. Gennem skole- og undervisningslitteratur og litteraturhistorien har opfattelsen spredt sig som et faktum, at vi i middelalderen dansede kædedans til ballader. Der er ingen tvivl om at ballader blev sunget og kædedansen danset. Men koblingen mellem de to udtryksformer i denne periode er ikke dokumenteret. Til gengæld ved vi - med visse hvis'er og måske'er - noget om kædedans i andre perioder og lidt om en kobling mellem kædedans og skæmteviser. Kilderne viser også at vi har en fælles kædedanstradition med andre vestlige og mellemøstlige lande hvor traditionen i visse områder stadig eksisterer.

Endelig skal det nævnes at netop beskrivelserne af tospring på den jyske vestkyst og trendansen på Mandø dannede grundlag for at balladesang til kædedans blev en del af den nye folkemusikinteresse i 1970'erne som specifikt interesserede sig for ældre danske folkemusiktraditioner. Denne bevægelsen ebbede i al væsentlighed ud i begyndelsen af 1990'erne. Efterfølgende blev oplevelseskulturens middelaldermarker et af de offentlige steder hvor man kunne - og måske stadig kan - se eller deltage i en kædedans med en forsanger der synger for i en ballade og dansere der synger omkvæd. Om eller hvor ballader og kædedans i sammenhæng dukker op næste gang, må tiden vise.

Artiklen bygger delvis på anden del af forfatterens bog Balladesang og kadedans $i$ Danmark - to aspekter af dansk folkevisekultur, 2015, s. 228-327. Heri findes yderligere kilder om dans der muligvis kan referere til kædedans i Danmark, bl.a. dans på kirkegårde i 1400-1500-tallet, skomagersvendene der danser rundt $\mathrm{i}$ Slagelse o. 1450, springdanse og springeviser i 1530'rne og dans rundt om den afdøde i 1600-1700-tallet. Og i de nærmeste nabolande: Olaus Magnus om sang til dans ved midsommerfesten i Sverige o. 1490-1557, og sang til to langdanse i Ditmarsken før 1595. 
"Møllerdatteren"

H. Grüner-Nielsen optegnede fem vers af skæmteballaden på Mandø i 1916. ${ }^{23}$

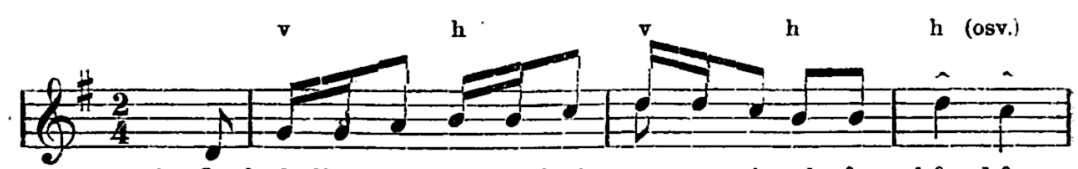

1. Og kæl - lin - gen stop - ped $\sin$ søn i sæk, a hå hå
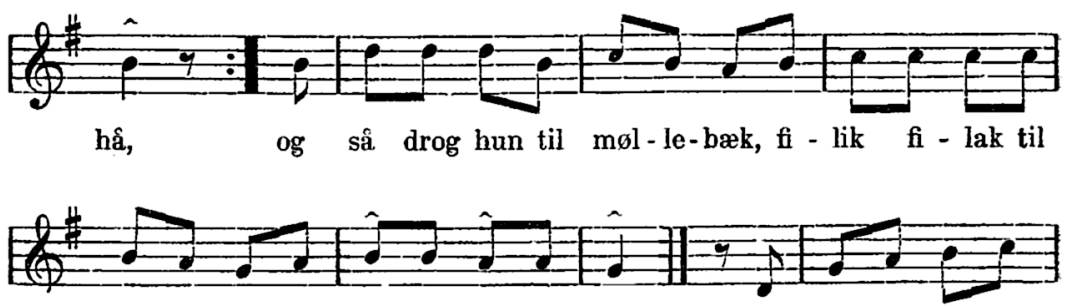

møl-le-bæk, fi - lik fi - lak fi-lej. 2. Den tid hun kom til

(osv.)

1. Og kællingen stopped' sin søn i sæk

$$
\text { a, hå hå bå }
$$

Og så drog hun til møllebæk

filik filak til mollebak filik filak filej

2. Den tid hun kom til møllerens hus da stod hr. møller og stamped' i vand

3. “Og hør du møller, fager og fin og vil du male posen min?"
4. "Ja, hvad har du i posen din?"

"Der har jeg rug og hvede så fin"

5. Og kællingen sank og posen flød a, hå bà hå

og al hendes mel det blev til grød filik filak det blev til grød filil filak filej 
"Otte bejlere"

Melodien er optegnet af H. Grüner Nielsen på Mandø, 1916. Teksten er nedskrevet af fru Jeffsen til Grüner-Nielsen. ${ }^{24}$

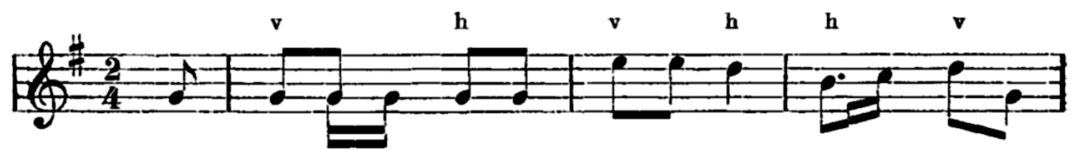

1. Der var en skön jom - fru pâ vort land, fal - la - la, der

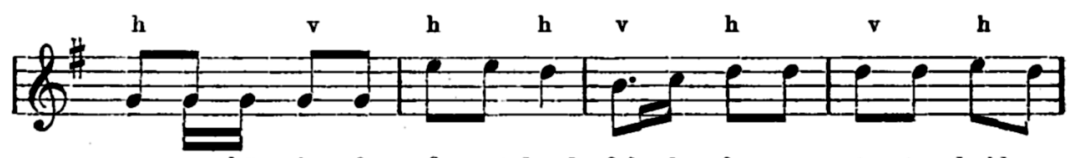

var en skön jom-fru på vort land, fal - la - la, og ot - te bej-ler
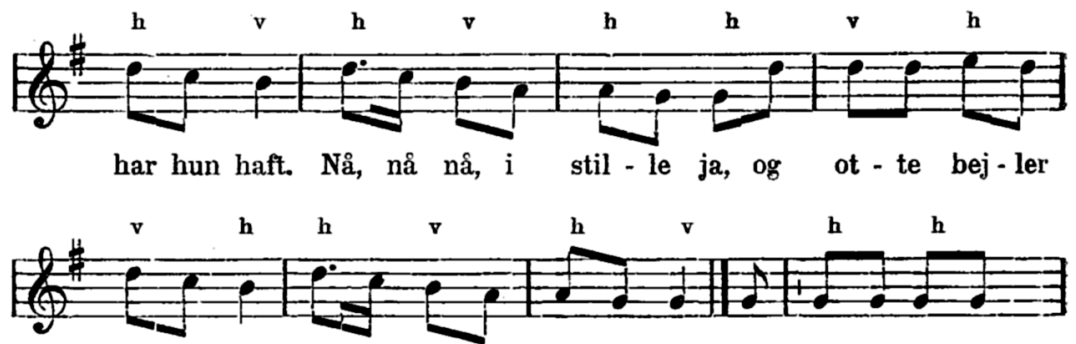

har hun haft. Nå, nå, nå, i stil - le ja. 2. Og hun bej i den (osv.)

1. /: Der var en skøn jomfru på vort land fallala:/

/: Og otte bejler har hun haft $n \mathfrak{a}, n \ddot{a}, n \dot{a}$, i stille ja* ${ }^{*} /$

2. Og hun bej i den første men han ville sig forlyste

3. Og hun bej i den anden men han var ej hende' ganden**

4. Og hun bej i den tredje men han var smal i midje

5. Den fjerde har så bred en hat og han kan skyde og det så brat
7. Den sjette han var så fager en svend men han rejst' bort og kom aldrig igen

8. Den syvend' han var så let i sind han kom kun jen sind til hend' ind

9. Den ottend' har guldterning i skrin derfor blev han allerkæreste min

10. Ja, nu kan a itt mer' af den nu må I andre kvæd' os jen

11. /: Ja, kvæd en let og kvæd en lang fallala:/

/: så vi kan hold' vor fødder i gang $n \dot{a}, n \dot{a}, n \dot{a}$, I stille ja* $: /$

6. Den femte var humpen og stumpet o bag * [stiller jer]

men han gjord' sig slet ingen umag' $\quad{ }^{* *}$ [ej hendes ven] 


\section{Noter}

1 Peder Palladius: Peder Palladius' Visitatsbog, udgivet af Lis Jacobsen. 1925 (1867), s. 56-57.

2 Spalte 333; H. Grüner-Nielsen: "Den ældste Landsindsamling af danske Folkemaal ved Matthias Moth omkring 1700. En oversigt over Kildestoffet og Redegørelse for dets kulturhistoriske og folkloristiske Betydning" i Sprog og Kultur 10, 1941, s. 80-114. S. 81-82.

3 S. 39; se også "Harboskræp" og "hofferdig" i Otto Kalkar: Ordbog til det eldre danske sprog (1300-1700), <www.kalkarsordbog. $\mathrm{dk}>$

4 H. Grüner-Nielsen: "Matthias Moths Landsindsamling af danske Ord 1697 1700" i Sprog og Kultur 7, 1939; samme “Den ældste Landsindsamling af danske Folkemaal ved Matthias Moth omkring 1700," 1941.

562 bind i katalognumrene GkS 769-777 fol.

6 www.mothsordbog.dk

7 Grüner-Nielsen: Vore aldste folkedanse. Langdans og polsdans (Danmarks Folkeminder 6). 1917, s. 17.

8 H. Grüner-Nielsen: "Den ældste Landsindsamling af danske Folkemaal ved Matthias Moth omkring 1700," 1941, s. 81.

9 H. Grüner-Nielsen: Vore aldste folkedanse. 1917, s. 15, nr. 12.

10 Palle Fløe: "Skikke og Levevis i den sydlige Del af Ringkjøbing Amt,"bd. III, 1870-71, s. 304. H. Grüner-Nielsen: Vore aldste folkedanse. 1917, s. $10 \mathrm{nr}$. $1 \mathrm{~b}$.
11 H. Grüner-Nielsen: Vore aldste folkedanse. 1917 , s. 13 nr. 7 a.

12 "Skikke og Levevis i den sydlige Del af Ringkjøbing Amt,"bd. III, 1870-71, s. 304; H. Grüner-Nielsen: Vore aldste folkedanse. 1917, s. $10 \mathrm{nr} .1 \mathrm{~b}$.

13 H. Grüner-Nielsen: Vore eldste folkedanse. 1917, s. 14 , nr 8.

14 Center for Jysk Dialektforskning: H.P. Hansens dagbogoptegnelser, Ms. 207.0, s. 233.

15 Dansk Folkemindesamling: DFS 1906/46, top. 2561 (Skjern Sogn).

16 H. Grüner-Nielsen: "Folkevisedans på Manø" i Danske Studier, 1917, s. 16-17.

17 "Møllerdatteren," også kendt fra Højskolesangbogen som "Der stode tre skalke," men $i$ en anden version. Og "Der er en jomfru i vort land," også kaldet "Otte bejlere."

18 Knud Kannik: "Den danske Middelalders kvaddans" i Danske Studier 22, 1925, s. 89. Iørn Piø: Nye veje til folkevisen. 1985, s. 292; ang. symbolske fortolkninger henvises til Dorthe Falcon Møller: Klang på kalk. Musiksymbolik i dansk kalkmaleri. 1996.

19 Eydun Andreassen: Folkelig offentlighed. 1992, s. 128

20 Jf. Roderyk Lange: The nature of dance. London, 1975, s. 56-57.

21 H. Grüner-Nielsen: "Folkevisedans på Manø," 1917, s. 20.

22 H. Grüner-Nielsen: Vore aldste folkedanse, 1917, s. 40. 